\title{
Solid organ donation from the emergency department - missed donor opportunities
}

\author{
Jessica McCallum $\odot, M^{*}$; Ryan Yip*; Sonny Dhanani, MD; Ian Stiell $\odot, M D, M^{*}{ }^{*}{ }^{*}$
}

\section{CLINICIAN'S CAPSULE}

What is known about the topic?

There is a deficit of solid organ donors in Canada, and we believe that many cases are missed in the emergency department (ED).

What did this study ask?

We evaluated the number of missed potential solid organ donors in a large tertiary ED.

What did this study find?

Cases were missed due to referral after withdrawal of life support and could have increased the donation rate by $10.6 \%$.

Why does this study matter to clinicians?

ED physicians should consider the possibility of organ donation prior to the withdrawal of life-sustaining therapy.

\section{ABSTRACT}

Objective: A significant gap exists between people awaiting solid organ transplantation and solid organ donors. The purpose of this study was to determine whether there were missed donors in the emergency department (ED).

Methods: We performed a health records and organ donation database review of all patients dying in a large tertiary ED from November 1, 2014 to October 31, 2017 at two campuses with 160,000 visits per year. Demographic and donor suitability data were collected. The primary outcome was missed potential solid organ donors. Missed potential donors were intubated, had a pulse, and had no donation contraindications. The secondary outcome was cases where no notification was made to the organ donation organization at all.

Results: There were 605 deaths in the ED. Patients had a mean age of 71.1 years, $58.3 \%$ were male, and $12.4 \%$ died of a traumatic cause. There were 10 missed potential donors. Missed potential donors had a mean age of 67.4 years, $70.0 \%$ were male, and $20.0 \%$ died from trauma. In all 10 cases, patients had withdrawal of life-sustaining therapy for medical futility, and referral for donation occurred after death. Missed ED donors could have increased hospital-wide donation up to $10.6 \%$. No notification was made in $12(2.0 \%)$ cases; however, none of these would have been successful solid organ donors. Conclusion: The ED is a source of missed organ donors. All potential donors were missed due to referral after withdrawal of life-sustaining therapy. ED physicians should consider the possibility of solid organ donation prior to the withdrawal of life-sustaining therapy.

\section{RÉSUMÉ}

Introduction: Un fossé profond sépare le nombre de malades dans l'attente d'une greffe d'organe solide et le nombre de donneurs potentiels. L'étude avait pour but de déterminer $s^{\prime}$ il y avait des occasions manquées de dons d'organes au service des urgences (SU).

Méthode: L'étude consistait en un examen de dossiers médicaux et d'une base de données sur les dons d'organes de tous les patients à l'agonie, entre le $1^{\mathrm{er}}$ novembre 2014 et le 31 octobre2017, dans un important SU de soins tertiaires, établi sur 2 campus et comptant 160000 consultations par année. Ont été recueillis des données démographiques ainsi que des renseignements sur la compatibilité des donneurs. Le principal critère d'évaluation était le nombre de donneurs potentiels d'organes solides, passés inaperçus. Étaient considérés comme tels les patients intubés, qui avaient un pouls et qui n'avaient pas de contre-indications à un don d'organes. Le critère secondaire d'évaluation visait les cas dans lesquels il n'y avait pas eu de communication avec l'organisation responsable des dons d'organes.

Résultats: Au total, 605 décès ont été enregistrés au SU. Les patients avaient un âge moyen de 71,1 ans, étaient des hommes dans $58,3 \%$ des cas et avaient succombé à un trauma dans $12,4 \%$ des cas. Dix donneurs potentiels sont passés inaperçus. Ceux-ci avaient un âge moyen de 67,4 ans, étaient des hommes dans $70,0 \%$ des cas et avaient succombé à un trauma dans $20,0 \%$ des cas. Chez les 10 donneurs passés inaperçus, on avait mis fin aux mesures de maintien des fonctions vitales pour cause d'acharnement thérapeutique, et les communications pour d'éventuels dons d'organes avaient été faites

From the *Department of Emergency Medicine; ${ }^{\dagger}$ Division of Critical Care, Department of Pediatrics, Faculty of Medicine, University of Ottawa, Ottawa ON; and the ${ }^{\ddagger}$ Ottawa Hospital Research Institute, Ottawa, ON.

Correspondence to: Dr. Jessica McCallum, Department of Emergency Medicine, University of Ottawa, 1053 Carling Avenue, Ottawa, ON K1Y 4E9; Email: j.harrismccallum@gmail.com

(C) Canadian Association of Emergency Physicians 
après la mort des patients concernés. Si ceux-ci avaient été reconnus comme donneurs potentiels au SU, le nombre de dons d'organes aurait pu augmenter de $10,6 \%$ à la grandeur de l'hôpital. Dans 12 cas $(2,0 \%)$, il n'y a eu de communication, mais aucun des patients concernés n'aurait pu faire un don d'organes solides.

Conclusion: Le fait est avéré : le SU est un lieu d'occasions manquées de dons d'organes. Dans tous les cas, les donneurs potentiels n'ont pas été considérés comme tels parce que les communications pour d'éventuels dons d'organes avaient été faites après l'interruption des mesures de maintien des fonctions vitales. Aussi les urgentologues devraient-ils envisager la possibilité de dons d'organes solides avant l'arrêt des mesures de maintien des fonctions vitales.

Keywords: Critical care, resuscitation, organ donation, transplant medicine

\section{INTRODUCTION}

There is a substantial gap between the number of people waiting for a solid organ transplant and the number of organ donors. Solid organs include the heart, lungs, liver, kidneys, pancreas, and small intestine. There are currently 1,628 people awaiting organ donation in Ontario alone. ${ }^{1}$ In 2018, 310 donors donated 858 organs. ${ }^{1}$ In British Columbia, there are currently 704 people awaiting an organ transplant, and 160 organs have been transplanted thus far in 2019. ${ }^{2}$ One solid organ donor can save up to eight lives through donating more than one organ. ${ }^{3}$ Considering the immediate need for organ donation, it is essential that all potential donors are identified and people are offered the opportunity to donate.

There are two populations of deceased solid organ donors. In neurologic determination of death, the donor no longer has brainstem reflexes and respiratory drive. ${ }^{4}$ In donation after circulatory determination of death, the heart stops, leading to a cessation of blood circulation. $^{5}$ A recent systematic review described populations of successful and missed organ donors from the emergency department (ED). ${ }^{6}$ This systematic review of 25 papers found that a wide range (4-50\%) of successful neurologic determination of death donors and 4$4.9 \%$ of donation after circulatory determination of death donors came from the ED. This review also found that many $(8-86 \%)$ missed neurologic determination of death donors, and up to $75 \%$ of donation after circulatory determination of death donors died in the ED. Therefore, the ED is a source of both successful and missed organ donors. Unfortunately, the data included in the recent systematic review were quite heterogeneous, and there were few studies reporting on Canadian institutions.

The purpose of this study was to determine whether there were missed potential solid organ donors in the
ED at our Canadian institution, and by what percent those missed donors could increase organ donation in the hospital overall. We also investigated what percentage of patients died without notification of the organ donation organization and successful hospital-wide donation.

\section{METHODS}

We performed a health records and organ donation database review at a large academic tertiary care centre with two campuses and 160,000 ED visits per year. All patients who died in the ED at the Ottawa Hospital were included. Patients were included from November 1, 2014 - October 31, 2017.

Data on all patients were cross-referenced between hospital records and the Ontario provincial organ donation organization called the Trillium Gift of Life Network to determine whether patients were appropriately referred for consideration of donation in a timely manner. The research ethics board approval was obtained from The Ottawa Hospital Clinical Research Ethics Board. A data sharing agreement was approved between the co-investigators and the Trillium Gift of Life Network. We collected data on demographics, cause of death, and suitability for organ donation (Table 1). All patients who died in the ED were manually screened for organ donation organization notification, referral for donation, and suitability according to donation criteria (data were not published). The organ donation organization provided their screening criteria with the understanding that it would not be disseminated to prevent the inappropriate exclusion of patients in the future, as the guidelines often change. In brief, exclusion criteria were based on age, past medical history, organ function, and resuscitation outcomes. If a patient was available in 


\begin{tabular}{lccc|}
\hline \multicolumn{4}{|l}{ Table 1. Demographics of the $\mathbf{6 0 5}$ study patients who died in the ED, not missed donors, and missed donors } \\
\hline Demographics & ED deaths $N=605$ & Not missed donors $N=595$ & Missed donors $N=10$ \\
\hline Age, mean in years (SD) & $71(59-87)$ & $71(70-73)$ & $67(64-71)$ \\
Sex, male, N (\%) & $353(58)$ & $345(58)$ & $7(70)$ \\
Cause of death & & & $2(20)$ \\
Traumatic, N (\%) & $75(12)$ & $73(12)$ & $8(80)$ \\
Non-traumatic, N (\%) & $530(88)$ & $522(88)$ & $4(50)$ \\
Cardiac & $247(46)$ & $243(47)$ & 0.53 \\
Malignancy & $41(8)$ & $41(8)$ & $2(25)$ \\
Pulmonary & $91(17)$ & $89(17)$ & $0(0)$ \\
Vascular & $18(3)$ & $18(3)$ & $2(25)$ \\
Neurologic & $38(7)$ & $36(7)$ & $0(0)$ \\
Septic & $77(15)$ & $77(15)$ & $0(0)$ \\
Renal & $9(2)$ & $9(2)$ & 0.35 \\
Gastrointestinal bleed & $3(1)$ & $3(1)$ & $0(0)$ \\
Overdose & $5(1)$ & $5(1)$ & $0(0)$ \\
Hypothermia & $1(0.2)$ & $1(0.2)$ & 0.35
\end{tabular}

health records data but not in donation data, Trillium Gift of Life Network was asked to re-check their database for the missing patient to confirm that the patient was not in their database. In these cases, patients were recorded as having no notification made.

Data were inputted into an $\mathrm{Excel}^{\odot}$ spreadsheet. RY collected data on a sample of 50 patients, and all data were re-screened by JM for quality and accuracy. RY then collected data on the remainder of the patients and JM re-screened a random sample of $10 \%$ of patients for quality and accuracy, and there was $100 \%$ agreement. $\mathrm{JM}$ also re-screened all cases where no notification was made to the organ donation organization and all potential missed organ donors. There was $100 \%$ agreement between RY and JM for these populations.

The primary outcome was the number of missed potential solid organ donors amongst all patients dying in the ED. To be classified as a missed potential solid organ donor, the patient needed to be intubated, have a pulse, and not have any exclusion criteria for solid organ donation. There were two secondary outcomes. One secondary outcome was patients who died without any notification to the organ donation organization. The other secondary outcome was the total number of successful organ donors hospital-wide during the time period of the study.

We calculated simple descriptive statistics for demographic and clinical data. The primary outcome analysis was the percentage increase of hospital-wide donors that the missed potential ED donors could have had. This was calculated by dividing the number of missed potential ED donors by the total number of hospital-wide donors during the same period. The secondary outcome analysis for cases where no notification to the organ donation organization was made and calculated as the number of cases where a notification was not made divided by the total number of patients who died in the ED. The data for the total number of successful donors are presented descriptively.

\section{RESULTS}

Ottawa Hospital health records provided data on 604 patients, and the Trillium Gift of Life Network provided data on 614 patients from the ED. Of the 10 additional patients, 5 had an invalid medical record number. Three patients were removed from health records data because they did not die in the ED, and one patient was removed because that patient had no data available, yielding 605 patients that were included in the study (Figure 1). Patients had a mean age of 71.1 years, $58.3 \%$ were male, and $87.6 \%$ died of a non-traumatic cause (see Table 1).

The primary outcome was the number of missed potential solid organ donors in the ED. There were 10 missed potential solid organ donors (see Table 1). The 10 missed potential donors had a mean age of 67.4 years, and $70.0 \%$ were male. All 10 cases had withdrawal of life-sustaining therapy, and a referral for donation was not made until after the patient died. Two of these 


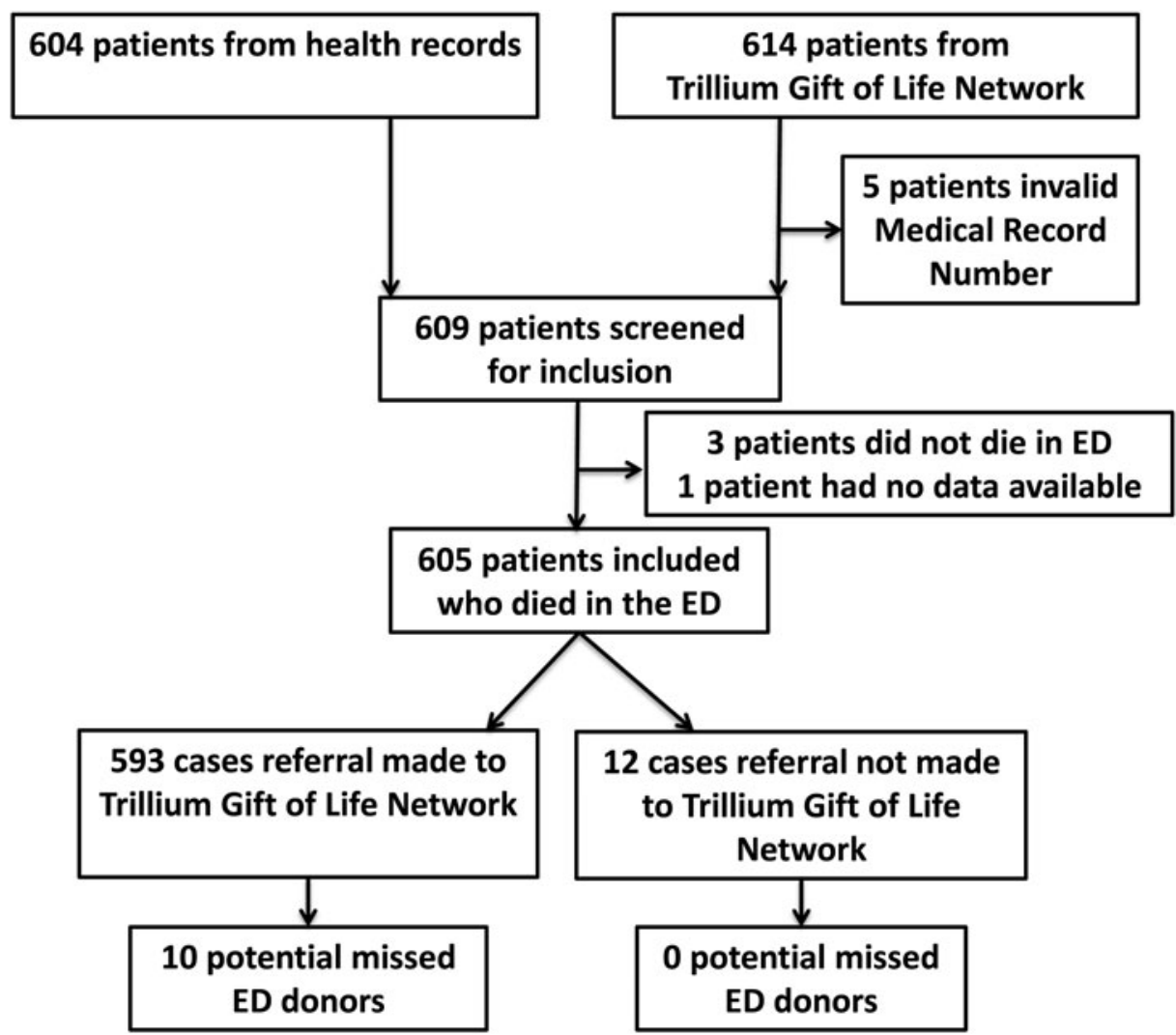

Figure 1. Patient flow diagram.

patients died of a traumatic cause and had an intracranial injury, two of these patients had a cerebrovascular accident, and six of these patients suffered a cardiac arrest, achieved return of spontaneous circulation, and later died.
During the time period of this study and throughout the entire hospital, there were 2 donors from the ED and 92 from the intensive care unit, yielding 94 total (Table 2). These donors donated a total of 394 organs, yielding a rate of 4.2 organs per donor. If all 10 missed

\begin{tabular}{|c|c|c|c|c|}
\hline & \multicolumn{2}{|c|}{ Emergency department $\mathrm{N}=2$} & \multicolumn{2}{|l|}{ Intensive care unit $\mathrm{N}=92$} \\
\hline & $\begin{array}{l}\text { Donation after circulatory } \\
\text { determination of death }\end{array}$ & $\begin{array}{l}\text { Neurologic } \\
\text { determination of death }\end{array}$ & $\begin{array}{l}\text { Donation after circulatory } \\
\text { determination of death }\end{array}$ & $\begin{array}{l}\text { Neurologic } \\
\text { determination of death }\end{array}$ \\
\hline Number of donors & 0 & 2 & 31 & 61 \\
\hline $\begin{array}{l}\text { Successful } \\
\text { donation rate* }\end{array}$ & 0 & $50.0 \%$ & $47.7 \%$ & $87.1 \%$ \\
\hline \multicolumn{5}{|l|}{ Organs donated } \\
\hline Heart & 0 & 2 & 0 & 23 \\
\hline Lungs & 0 & 0 & 10 & 39 \\
\hline Liver & 0 & 2 & 4 & 46 \\
\hline Kidney & 0 & 4 & 57 & 98 \\
\hline Pancreas & 0 & 2 & 3 & 12 \\
\hline Small intestine & 0 & 0 & 0 & 0 \\
\hline Total & 0 & 10 & 105 & 279 \\
\hline
\end{tabular}




\begin{tabular}{|c|c|c|c|}
\hline Demographics & Notification made $\mathrm{N}=593$ & No notification made $\mathrm{N}=12$ & $p$-value \\
\hline Age, mean in years (SD) & $71(70-73)$ & $66(47-85)$ & 0.03 \\
\hline Sex, male, N (\%) & $345(58)$ & $7(58)$ & 1 \\
\hline \multicolumn{4}{|l|}{ Cause of death } \\
\hline Traumatic, N (\%) & $69(12)$ & $6(50)$ & $<0.01$ \\
\hline Non-traumatic, N (\%) & $524(89)$ & $6(50)$ & $<0.01$ \\
\hline Cardiac & $244(47)$ & $3(50)$ & \\
\hline Malignancy & $41(8)$ & 0 & \\
\hline Pulmonary & $90(17)$ & $1(17)$ & \\
\hline Vascular & $18(3)$ & 0 & \\
\hline Neurologic & $36(7)$ & 2 (33) & \\
\hline Septic & $77(15)$ & 0 & \\
\hline Renal & $9(2)$ & 0 & \\
\hline Gastrointestinal bleed & $3(1)$ & 0 & \\
\hline Overdose & $5(1)$ & 0 & \\
\hline Hypothermia & $1(0.2)$ & 0 & \\
\hline
\end{tabular}

potential donors had successfully gone on to donate organs, the overall hospital donation rate could have increased by $10.6 \%$. Considering the hospital successful donation rate (number of successful donors/number of potential donors approached) is $50.0 \%$ to $87.1 \%$ (see Table 2), a more realistic estimate of the potential increase in donation rate would be $5.1 \%$ up to $9.2 \%$.

The secondary outcome in this study was cases where the organ donation organization was not notified at all. No notification was made in 12 cases $(2.0 \%)$ amongst patients who died in the ED (Table 3). These cases were more likely to be of younger patients $(66.0 \mathrm{v} .71 .2$ years, $p=0.03$ ) and patients who died of a traumatic cause $(50.0 \%$ v. $12.4 \%, p<0.01)$; however, there was a bimodal age distribution. A chart review of these 12 cases did not reveal any specific reasons why notification did not occur. None of these cases would have been eligible for donation because they either did not regain a pulse or had an absolute contraindication to a solid organ donation (see Figure 1).

\section{DISCUSSION}

We found that the ED was a source of missed potential solid organ donors and could have increased the institutional donation rate by up to $10.6 \%$. All potential donors were missed due to the withdrawal of life-sustaining therapy occurring prior to contacting the provincial organ donation organization. Therefore, donors were missed due to referral after death. We also found several cases where no notification was made to the organ donation organization at all, most often in young trauma patients.

A previous systematic review found the ED to be a source of actual and missed solid organ donors. ${ }^{6}$ In brief, $4-50 \%$ of successful neurologic determination of death donors came from the ED and 3.6-8.9\% of successful donation after circulatory determination of death donors came from the ED. ${ }^{6}$ In studies investigating potential future donation programs, $2.0-7.2 \%$ of patients dying in the ED could have been a neurologic determination of death donors, and $0.3-0.5 \%$ of patients dying in the ED could have been a donation after circulatory determination of death donors. ${ }^{6}$ A retrospective cohort study was done in 2017 using the Ontario organ donation database on patients who died in a referral hospital over 2 years to investigate missed donor opportunities. They found that, after the withdrawal of life-sustaining therapy, $54 \%$ of patients could have been medically suitable for donation after circulatory determination of death; however, only $66.2 \%$ of these patients were appropriately referred. ${ }^{7}$ They concluded that medically suitable patients dying within an appropriate time frame after the withdrawal of life-sustaining therapy was nearly six times higher than the actual number of organ donors over the same time period. This is similar to the results of our study and highlights that a 
significant number of potential donor opportunities are missed due to lack of a timely referral, specifically after the withdrawal of life-sustaining therapy has already occurred.

There are limitations of our study. This was a health records/database study and is limited by the biases associated with this study design, but this was mitigated through the re-screening of all charts according to current organ donation criteria. Also, not all missed potential donors would necessarily result in a successful donation. We attempted to mitigate this by including the successful donation rate at our institution (see Table 3). The strengths of this study are that it is the first study we are aware of that investigated missed donation opportunities exclusively in ED patients in Canada and all charts were manually re-screened for suitability for organ donation.

There are several potential clinical implications. Regarding missed donors, it is striking that all potential donors were missed for the one reason (referral for donation after the withdrawal of life-sustaining therapy), which is supported by previous evidence. ${ }^{7}$ At our institution, the bedside nurse is responsible for contacting the organ donation organization. An education initiative could be designed focusing on ensuring a referral for organ donation prior to the withdrawal of life-sustaining therapy. This will allow time for the organ and tissue donation coordinator to screen patients for medical suitability and approach families for consent. Canadian donation guidelines recommend that it should be an organ donation organization that approaches families to discuss the opportunity to donate, which would decrease the burden on ED healthcare providers. ${ }^{8}$ The cases where a notification was never made to the Trillium Gift of Life Network are significant, as provincial law in Ontario mandates that the Trillium Gift of Life Network be notified as soon as possible after death, or if a physician believes that the death of a patient is imminent (Trillium Gift of Life Network Act, R.S.O 1990, c. H.20 Part II.1 8.1). No notification of the organ donation organization prevents the opportunity for donation for families and may be contrary to the wishes of the dying patient if they wished to be an organ donor. The Trillium Gift of Life Network also does monthly deceased donation reviews. Although none of the patients who had no notification were missed solid organ donors, they may have had tissue donation potential and one tissue donor can impact up to 75 lives. $^{3}$ It is important that emergency physicians are familiar with their local organ donation referral policies and procedures, as emergency physicians will guide decisions regarding withdrawal of life-sustaining therapy.

Future research could investigate the impact of an ED-specific education program on notification and referral rate. Additionally, a survey could be designed to investigate actual and perceived barriers to a timely referral of organ donors in the ED. Previous literature has highlighted that some ED healthcare providers feel the ED is inappropriate for broaching, promoting, and requesting organ donation and that healthcare provider influence can decrease donation rates. ${ }^{9}$ This is suboptimal, as other studies have highlighted increased consent rates by families and successful organ transplantation from the ED specifically. ${ }^{10,11}$ Furthermore, a quality improvement analysis could determine factors that may lead to a referral for donation, specifically after the withdrawal of life-sustaining therapy in the ED, because there may be actual or perceived barriers to donation in this particular context. Once these barriers are identified, potential solutions can be proposed and investigated to address this gap. Given the organ donor shortage, it is essential to explore these beliefs and address healthcare provider concerns in the ED. ${ }^{12}$

\section{CONCLUSION}

The ED is a source of missed organ donors. All potential donors were missed due to referral after death after the withdrawal of life-sustaining therapy. ED physicians should consider the possibility of solid organ donation prior to the withdrawal of life-sustaining therapy.

Acknowledgements: We would like to thank Angela Marcantonio for her expertise and assistance with the ethics application and My-Linh Tran for performing the statistical analysis. We would like to also thank the Trillium Gift of Life Network, 2018, Toronto, Ontario, for their support in providing data from their database. Finally, we would like to thank the Department of Emergency Medicine in Ottawa, Ontario, for funding this study.

Competing interests: None declared.

\section{REFERENCES}

1. Trillium Gift of Life Network - Ontario's Organ and Tissue Donation Agency: public reporting; 2018. Available at: https://www.giftoflife.on.ca/en/publicreporting.htm (accessed September 15, 2018). 
2. Transplant BC. BC transplant current statistics; 2019. Available at: http://www.transplant.bc.ca/Documents/Statistics (accessed May 6, 2019).

3. Network TGOL. Organ and tissue donation: the facts; 2019. Available at: https://www.beadonor.ca/about-donation (accessed May 6, 2019).

4. Shemie SD. Severe brain injury to neurological determination of death: Canadian forum recommendations. CMAJ 2006;174(6):S1-12.

5. Thuong M, Ruiz A, Evrard P, et al. New classification of donation after circulatory death donors definitions and terminology. Transpl Int 2016;29(7):749-59.

6. McCallum J, Ellis B, Dhanani S, Stiell IG. Solid organ donation from the emergency department - a systematic review. CFEM 2019;21(5):626-37.

7. Krmpotic K, Payne C, Isenor C, Dhanani S. Delayed referral results in missed opportunities for organ donation after circulatory death. Crit Care Med 2017;45(6):989-92.
8. Shemie SD, Robertson A, Beitel J, et al. End-of-life conversations with families of potential donors. Transplantation 2017;101:S17-26.

9. Jawoniyi O, Gormley K, McGleenan E, Noble HR. Organ donation and transplantation: awareness and roles of healthcare professionals - a systematic literature review, 3rd ed. 7 Clin Nurs 2018; 27(5-6):e726-38.

10. Miller LD, Gardiner SK, Gubler KD. Emergency department referral for organ donation: more organ donors and more organs per donor. Am $\mathcal{F}$ Surg 2014;207(5):72833, discussion 733-4.

11. Michael GE, O'Connor RE. The importance of emergency medicine in organ donation: successful donation is more likely when potential donors are referred from the emergency department. Acad Emerg Med 2009;16(9):850-8.

12. Healey A, Singh JM. Organ donation - emergency medicine's call to action. CFEM 2019;21(05):569-71. 